\title{
MIR432 wt Allele
}

National Cancer Institute

\section{Source}

National Cancer Institute. MIR432 wt Allele. NCI Thesaurus. Code C82197.

The human MIR432 wild-type allele is located in the vicinity of $14 \mathrm{q} 32.31$ and is approximately 93 bases in length. This allele, which encodes MIR432 pre-miRNA, plays a role in the regulation of gene expression. Alteration in the expression of this gene is associated with development of epithelial ovarian cancer. 